ROCZNIKI TEOLOGICZNE

Tom LXVIII, zeszyt $8-2021$

DOI: https://doi.org/10.18290/rt21688.5

\title{
NIEPOKALANE POCZECIE NAJŚWIĘTSZEJ MARYI PANNY W LEX ORANDI KOŚCIOŁA W ŚWIETLE OFICJUM WOTYWNEGO PO SOBORZE TRYDENCKIM
}

\author{
IMMACULATE CONCEPTION OF THE BLASSED VIRGIN MARY \\ IN THE LEX ORANDI OF THE CHURCH IN THE LIGHT OF VOTIVE OFFICE \\ SINCE THE COUNCIL OF TRENT
}

\begin{abstract}
A b s t r a c t. The liturgy as theologia prima has played an important role in forming awareness of the truths of the faith which form the foundation of prayer: lex orandi. This reciprocal relationship of lex crednedi-lex orandi was at the foundation of the formulation of the dogma of the Immaculate Conception of the Blessed Virgin Mary in Pope Pius IX's bull of December 8, 1854, Ineffabilis Deus. While this feast was celebrated once a year, a more frequent opportunity to celebrate this mystery-even weekly-was provided by the votive office, which was introduced into the Officium Divinum in 1727, and after the proclamation of the dogma in 1854, new texts were ultimately approved in 1863. The votive office was removed in 1912 . The liturgical texts have permitted presenting the mystery of the Conception of the Blessed Virgin Mary in the lex orandi of the Church since the Council of Trent. They emphasize the close relationship between the Immaculate Conception and the virginal maternity of Mary. From eternity Mary had been prepared by God Himself as a pure dwelling place for His Son. In receiving this privilege from God, Mary did not lose her virginity. It was therefore important to show the beauty of Mary against the background of the mystery of original sin and the promise of the protoevangelium of the Book of Genesis. This idea was emphasized in the office by texts from the Book of Wisdom and the Song of Songs, as well as texts from the Fathers of the Church. In praising the Virgin Mary with the words of the votive office, her intercession is entreated for everyday life, and also for help in striving for salvation. Reading
\end{abstract}

Dr hab. WALDEMAR PAŁECKI MSF, prof. KUL - Katedra Historii Liturgii, Katolicki Uniwersytet Lubelski Jana Pawła II; adres do korespondencji: Al. Racławickie 14, 20-950 Lublin; e-mail: waldemar.palecki@kul.pl; ORCID: https://orcid.org/0000-0002-2154-9356. 
and meditating on the liturgical texts thus shapes a proper perception of devotion to Mary in the tradition of the Western Church.

Keywords: liturgy; Immaculate Conception of the Blassed Virgin Mary; Votive Office; Council of Trent.

W historii Kościoła ważną rolę w kształtowaniu się coraz większej świadomości prawd wiary odegrała liturgia. Na istniejący związek pomiędzy dogmatem a modlitwą zwrócono uwagę dzięki myśli Prospera z Akwitanii (zm. po 455), który po 440 r. został sekretarzem papieża Leona Wielkiego (zm. 461) $)^{1}$. Podstawowym jego stwierdzeniem, wręcz aksjomatem czy adagium, ukazującym wzajemną relację między teologią a liturgią, jest zdanie: ut legem credendi lex statuat supplicandi (,,aby prawo wiary stanowiło prawo modlitwy") ${ }^{2}$. Zgodnie z tą myślą w ciągu wieków ważną rolę odegrało ukazywanie wzajemnych relacji pomiędzy lex orandi a lex credendi, aby poszukiwać źródeł leżących u podstaw prawd wiary. Stało się ono podstawą odnowy liturgicznej przez Prospera Guérangera OSB (zm. 1875), a także między innymi argumentem dla ogłoszenia dogmatu o Niepokalanym Poczęciu Najświętszej Maryi Panny przez Piusa IX (1846-1878), wprowadzenia przez papieża Piusa XI (1922-1939) do kalendarza liturgicznego święta Chrystusa Króla, czy ustanowienia przez papieża Piusa XII (1939-1958) dogmatu o Wniebowzięciu Najświętszej Maryi Panny ${ }^{3}$.

Od początku chrześcijaństwa szczególnym miejscem wyrazu wiary w modlitwie Kościoła jest Eucharystia i Officium Divinum. Modlitwa liturgiczna kształtowała się w ciągu wieków wraz z rozwojem roku liturgicznego i dotyczyła poszczególnych świąt i dni liturgicznych. W niektórych edycjach brewiarza rzymskiego jeszcze przed Soborem Trydenckim można odnaleźć również oficja wotywne, które nie były związane z konkretnymi dniami liturgicznymi. Przykładem jest brewiarz włocławski z 1542 r., w którym przewidziano następujące oficja: w poniedziałki o Apostołach, we wtorki o św. Wojciechu, w środy o św. Jadwidze, w czwartki o św. Stanisławie biskupie i męczenniku, a w piątki o męczennikach ${ }^{4}$.

\footnotetext{
${ }^{1}$ Por. Rafał Marcin Leszczyński, „Prosper z Akwitanii”, w Encyklopedia Katolicka, t. 16, red. Edward Gigilewicz (Lublin: Towarzystwo Naukowe KUL, 2012), 509.

${ }^{2}$ Prosper ex Aquitania, Liber cui titulus praeteritorum sedis apostolicae episcoporum auctoritates, de gratia Dei et libero voluntatis arbitrio, PL 51, 209.

${ }^{3}$ Por. Bogusław Nadolski, Leksykon liturgii (Poznań: Pallottinum, 2006), 735.

${ }^{4}$ Por. Antoni Julian Nowowiejski, Wyktad Liturgji Kościoła Katolickiego, t. IV, cz. II
} 
Od XVIII w. w Kościele Zachodnim w brewiarzach umieszczano oficja wotywne, które pozwalały celebrować prawdy wiary w cyklu częstszym niż tylko raz w roku - najczęściej cotygodniowym. Do nich należało również oficjum wotywne o Niepokalanym Poczęciu Najświętszej Maryi Panny, którego teksty po ogłoszeniu dogmatu tej prawdy przez papieża Piusa IX - zostały początkowo zmienione w 1855 r., a ostateczna ich wersja została zatwierdzona w 1863 r. $^{5}$ Interesującym zagadnieniem będzie więc przedstawienie na podstawie tekstów liturgicznych tego oficjum wotywnego istotnych treści teologicznych dotyczących Niepokalanego Poczęcia Najświętszej Maryi Panny na tle historii liturgii.

\section{POTRYDENCKA REFORMA BREWIARZA A OFICJA WOTYWNE}

Powstanie oficjów wotywnych wpisuje się w całą reformę brewiarza rzymskiego, która została przygotowana za papieża Piusa IV (1559-1565). Papież ten powołał komisję, której zadaniem było opracowanie nowej księgi liturgicznej, która została wydana za św. papieża Piusa V (1566-1572) w 1568 r. ${ }^{6}$ Pierwsze edycje Breviarium Romanum nie zawierają oficjów wotywnych. Dekrety wprowadzające te oficja były zamieszczane w brewiarzach od początku XVIII w., a najstarszy z nich był sygnowany data 20 marca 1706 r. $^{7}$ Wobec powstałych wątpliwości, dotyczących w jakim czasie oficja te mogły być odmawiane, Kongregacja Obrzędów wydała stosowny dekret Urbis et Orbis, według którego mogły one być recytowane we wszystkie dni poza Wielkim Postem, Adwentem, wigiliami świąt, oraz poza dniami kwartalnymi ${ }^{8}$. Samo pojęcie votum oznaczało prośbę, pragnienie czy życzenie, które kierowano do Boga, wspominając przy tym określone tajemnice ${ }^{9}$.

(Płock: Tłocznia „Kurjera płockiego” i „Mazura”, 1916), 312.

${ }^{5}$ Por. Andrzej Rutkowski, „Niepokalane Poczęcie NMP. III Kult”, w Encyklopedia Katolicka, t. 13, red. Edward Gigilewicz (Lublin: Towarzystwo Naukowe KUL, 2009), 1170.

${ }^{6}$ Por. Manlio Sodi, Achille Maria Triacca, „Introduzione”, w Breviarium Romanum. Editio Princeps (1568). Edizione anastatica, Introduzione e Appendice, ed. Manlio Sodi, Achille Maria Triacca (Città del Vaticano: Libreria Editrice Vaticana, 1999), XV.

${ }^{7}$ Por. Nowowiejski, Wykład Liturgji Kościoła Katolickiego, 237.

${ }^{8}$ Por. Decreta authentica Congregationis Sacrorum Rituum ex actis ejusdem Sacr. Congr. collecta cura et studio sacerdotis Aloysii Gardellini ejusdem S.R.C. assesoris, et sub-promotoris fidei, Editio altera emendator, Tomus quartus (Romae: Typis Francisci, et Leopoldi Bourlié, MDCCCXXV), 38-39.

${ }^{9}$ Por. Alojzy Jougan, Stownik kościelny tacińsko-polski (Warszawa: Wydawnictwo Archi- 
Do najbardziej znanych oficjów wotywnych po Soborze Trydenckim należało oficjum o Najświętszym Sakramencie, które odmawiano w czwartki. Zostało ono zaaprobowane przez papieża Klemensa XI (1700-1721) 17 sierpnia 1715 r. dla krajów, które były podległe cesarzowi Austrii. Można było je odmawiać w ciągu roku za wyjątkiem Adwentu i Wielkiego Postu, w wigilie świąt i wówczas, gdy przypadały oficja dzięwięciolekcyjne. Oficjum to odmawiano $\mathrm{w}$ rycie połowicznym ${ }^{10}$.

Innym oficjum wotywnym, sprawowanym w soboty, było oficjum o Poczęciu Najświętszej Maryi Panny. Również zostało ono zaaprobowane przez Benedykta XIII (1724-1730) 15 grudnia 1727 r. dla krajów znajdujących się pod władzą Austrii ${ }^{11}$. Według dekretu Urbis et Orbis papieża Piusa IX z 25 września 1863 r. teksty liturgiczne tego oficjum zostały ostatecznie zmienione i ułożone głównie wokół bulli Ineffabilis Deus ${ }^{12}$.

Wprawdzie oficja wotywne zostały dopuszczone przez Kościół, ale Kongregacja Obrzędów starała się ograniczyć ich liczbę, a stosowny dekret został wydany 7 lipca 1753 r. Zaznaczono w nim, że oficja te powinny być odmawiane tylko raz w tygodniu, albo tylko raz w miesiącu ${ }^{13}$. Dekret ten potwierdzono 11 maja $1816 \mathrm{r}$. i miał on dotyczyć również innych oficjów wotywnych ${ }^{14}$. Ostatecznie za papieża Grzegorza XVI (1831-1846) 23 maja 1835 r. potwierdzono

diecezji Warszawskiej, 1992), 740-741.

${ }^{10}$ Por. Breviarium Romanum. Ex decreto Sacrosancti Concilii Tridentini restitutum, S. Pii V. Pontificis Maximi jussu editum, Clementis VIII. \& Urbani VIII. Aauctoritate recognitum. In quo officia novissima sanctorum accurate sunt disposita, Ex ducali Campidonensi Typograheo, Per Aloysium Galler, Anno Domini MDCCLXXVIII, s. CCXLII [dalej: BR 1778].

${ }^{11}$ Por. Nowowiejski, Wykład Liturgji Kościoła Katolickiego, 312.

12 Por. Decreta authentica Congregationis Sacrorum Rituum ex actis eiusdem collecta, eiusque Auctoritate promulgata sub auspiciis ss. Domini Nostri Leonis Papae XIII (Vol III, Romae: Ex Typographia Polyglotta, MDCCCC), 155.

13 „Eminentissimi Patres S. R. C. praepositi decreverunt, quod in posterum preces recitandi Officia votiva semel in hebdomada, vel semel in mense, amplius non recipiantur"; Decreta authentica Congregationis Sacrorum Rituum ex actis ejusdem Sacr. Congr. collecta cura et studio sacerdotis Aloysii Gardellini ejusdem S.R.C. assesoris, et sub-promotoris fidei, Editio altera emendator, Tomus quartus (Romae: Typis Francisci, et Leopoldi Bourlié, MDCCCXXV), 359.

14 „Frequentes petitiones fiant pro facultate recitandi hujusmodi Officia votiva, nec petentes tam facile acquiescant, rati, quod praefata generalis dispositio ob diuturnum temporis lapsum in desuetudinem abierit"; Decreta authentica Congregationis Sacrorum Rituum ex actis ejusdem Sacr. Congr. collecta cura et studio sacerdotis Aloysii Gardellini ejusdem S.R.C. assesoris, et sub-promotoris fidei, Editio altera emendator, Tomus quintus (Romae: Typis Francisci, et Leopoldi Bourlié, MDCCCXXV), 203. 
zwyczaj odmawiania tylko dwóch oficjów wotywnych: o Najświętszym Sakramencie i Niepokalanym Poczęciu Najświętszej Maryi Panny ${ }^{15}$.

Rozwój oficjów wotywnych miał miejsce za papieża Leona XIII (18781903). Od 1883 r. pośród oficjów wotywnych można było rozróżnić oficja nadane przez Stolicę Apostolską oraz te, które były oficjami dowolnymi i odmawiano je z osobistej pobożności ${ }^{16}$. Papież Leon XIII 28 czerwca $1883 \mathrm{r}$. podczas audiencji wyraził zgodę na wprowadzenie nowych oficjów wotywnych. Odpowiedni dekret Kongregacja Obrzędów wydała 5 lipca 1883 r. ${ }^{17}$ Mogły być one odmawiane poza świętami oraz ostatnimi dniami Adwentu ${ }^{18}$.

Indult Kongregacji Obrzędów zezwalał na wprowadzenie przez kapituły i wspólnoty zakonne własnych oficjów odmawianych w dni ferialne poza Środą Popielcową, okresem Męki Pańskiej oraz poza czasem adwentowym od 17 do 24 grudnia. Na wspólne odmawianie oficjów wotywnych w chórze zgodę wydawał miejscowy ordynariusz, natomiast prywatnie można je było odmawiać dowolnie. Obligatoryjnie należało odmawiać, jeżeli było nakazane dekretem Stolicy Apostolskiej ${ }^{19}$. W wyniku reformy papieża Leona XIII oficja wotywne przyporządkowane zostały poszczególnym dniom tygodnia: w poniedziałki o Aniołach, we wtorki o św. Apostołach - a w samym Rzymie o świętych Piotrze i Pawle, w środy o św. Józefie, w czwartki o Najświętszym Sakramencie, w piątki o Męce Pańskiej i w soboty o Niepokalanym Poczęciu Najświętszej Maryi Panny ${ }^{20}$. Teksty oficjów wotywnych zostały opublikowane w Acta Sanctae Sedis ${ }^{21}$. Odpowiadały im również msze wotywne sprawowane $w$ tych samych tajemnicach w te same dni tygodnia ${ }^{22}$. W odpowiedzi na dubia Kongregacja Obrzędów 24 listopada 1883 r. przy-

\footnotetext{
${ }^{15}$ Por. Decreta authentica Congregationis Sacrorum Rituum nunc primum ex actis ejusdem S. Congregationis collecta. Continuatio appendicis (Romae: Typis S. Congregationis de Propaganda Fide, MDCCCXLIX), 215-217.

${ }^{16}$ Por. Nowowiejski, Wykład Liturgji Kościoła Katolickiego, 311.

17 Por. S. Congregatio Rituum, Decretum Urbis et orbis, ASS 16(1883/1884), 47. 593-594.

${ }^{8}$ Por. Suitbert Bäumer, Geschichte des Breviers (Freiburg im Breisgau: Herder, 1895),

19 Por. Decreta authentica Congregationis Sacrorum Rituum ex actis eiusdem collecta, eiusque Auctoritate promulgata sub auspiciis ss. Domini Nostri Leonis Papae XIII. Vol III (Romae: Ex Typographia Polyglotta, MDCCCC), 153.

${ }^{20}$ Por. Nowowiejski, Wykład Liturgji Kościoła Katolickiego, 313-314.

21 Por. S. Congregatio Rituum, „Officia votiva per annum”, Acta Sanctae Sedis 16(1883/1884): 146-176.

22 Por. S. Congregatio Rituum, „Missae votivae per annum”, Acta Sanctae Sedis 16(1883/ 1884): 176.
} 
pomniała, że podczas oficjum wotywnego o Męce Pańskiej nie dodawano w okresie paschalnym Alleluja i zawsze należało używać szat koloru czerwo$\mathrm{nego}^{23}$. Zasady natomiast dotyczące celebrowania mszy wotywnych zostały omówione w dekrecie Kongregacji Obrzędów z 30 czerwca 1896 r. ${ }^{24}$

Kres oficjom wotywnym położyła reforma papieża Piusa X (1903-1914) i bulla Divino afflatu wydana w $1911 \mathrm{r}^{25}$ Stosowne wytyczne zostały opublikowane przez Kongregację Obrzędów w Rubricae in recitatione divini officii et in missarum celebratione servandae ad normam constitutionis Apostolicae „Divino affla$t u$ ” w rozdziale siódmym. Zaznaczono tu, że wszystkie oficja wotywne, które zostały wprowadzone dekretem z 5 lipca 1883 r., skreślono ostatecznie na mocy dekretów z 24 i 28 lipca 1911 r. $^{26}$ Odpowiednie wskazania wykonawcze, co do reformy, Kongregacja Obrzędów opublikowała w dekrecie Urbis et Orbis z 23 stycznia 1912 r. $^{27} \mathrm{O}$ zniesieniu oficjów wotywnych Kongregacja Obrzędów przypomniała w dekrecie z 10 marca $1913 \mathrm{r}^{28}$

\section{DZIEWICZE MACIERZYŃSTWO NIEPOKALANIE POCZETEJ}

Prawda o poczęciu Najświętszej Maryi Panny i zachowania całkowitej bezgrzeszności Maryi była znana od V w. w tradycji pelagiańskiej, a od VII w. obchodzono oddzielne święto w Kościele wschodnim ${ }^{29}$. Wprawdzie od IX w. obchodzono je na Zachodzie, ale ze względu na powszechność grzechu pierworodnego teologowie scholastyczni przeciwstawiali się jego wprowadzeniu. Przełomem była myśl Dunsa Szkota (zm. 1308), który podkreślił znacze-

${ }^{23}$ Por. Decreta authentica Congregationis Sacrorum Rituum ex actis eiusdem collecta, eiusque Auctoritate promulgata sub auspiciis ss. Domini Nostri Leonis Papae XIII. Vol III (Romae: Ex Typographia Polyglotta, MDCCCC), 154.

${ }^{24}$ Por. tamże, 311-314.

${ }^{25}$ Por. Wojciech Danielski, „Brewiarz”, w Encyklopedia Katolicka, t. 2, red. Feliks Gryglewicz (Lublin: Towarzystwo Naukowe KUL, 1995), 1067.

${ }^{26}$ Por. S. Congregatio Rituum, „Rubricae in recitatione divini officii et in missarum celebratione servandae ad normam constitutionis Apostolicae Divino afflatu", Acta Apostolicae Sedis 3(1911): 646.

${ }^{27}$ Por. S. Congregatio Rituum, „Urbis et orbis”, Acta Apostolicae Sedis 4(1912): 78.

28 Por. S. Congregatio Rituum, „Decretum: De privilegio officii divini iuxta veterem psalterii ordinem recitandi”, Acta Apostolicae Sedis 5(1913): 97.

${ }^{29}$ Por. Stanisław Napiórkowski, „Niepokalane Poczęcie NMP. I. Teologia. 1. W Kościele katolickim", w Encyklopedia Katolicka, t. 13, red. Edward Gigilewicz (Lublin: Towarzystwo Naukowe KUL, 2009), 1166. 
nie pojęcia doskonałego Odkupiciela oraz argument chwały Jezusa Chrystusa, ze względu na predestynowanie Jej na Matkę Chrystusa ${ }^{30}$. Zdogmatyzowanie tej prawdy miało miejsce na schizmatyckim Soborze w Bazylei w 1439 r. $^{31}$ Prawda ta znalazła swój wyraz w kolejnych dokumentach papieskich, aż po ogłoszenie przez papieża Piusa IX dogmatu o Niepokalanym Poczęciu Najświętszej Maryi Panny. Jak postanowiono: „...Najświętsza Dziewica Maryja w pierwszej chwili swego Poczęcia za szczególniejszą łaską i przywilejem Boga Wszechmogącego, przez wzgląd na przyszłe zasługi Jezusa Chrystusa Zbawiciela rodzaju ludzkiego zachowana była wolną od wszelkiej zmazy pierworodnej winy..."32

Chrystocentryczne ujęcie prawdy o Poczęciu Najświętszej Maryi Panny znalazło swoje odzwierciedlenie w tekstach liturgicznych oficjum wotywnego. O takim ujęciu kultu świadczy już samo invitatorium. Według odnowionego oficjum wotywnego za papieża Piusa IX podkreślano, że obchodzenie Niepokalanego Poczęcia Dziewicy Maryi ma prowadzić do uwielbienia Jej Syna Chrystusa ${ }^{33}$.

$\mathrm{Na}$ pierwszym miejscu teksty liturgiczne ukazują prawdę o zachowaniu czystości i świętości ze względu na dziewicze macierzyństwo Bogarodzicy. Pan od wieków przygotował bowiem w Maryi swoje mieszkanie, a podkreślają to antyfony do psalmów I nokturnu, które po 1854 r. zostały zaczerpnięte z oficjum uroczystości. Słowami tych tekstów liturgicznych wychwalano godne podziwu imię Pana na całej ziemi (por. Ps 8,2), który w dziewiczej Maryi przygotował swoje mieszkanie. To Bóg bowiem na słońcu ustanowił swój przybytek (por. Ps 19[18],6), a w poczęciu swym Maryja przyjęła błogosławieństwo od Pana i miłosierdzie od swego Zbawcy (Ps 24[23],5) ${ }^{34}$. W wersecie przed czytaniami podkreślano, że Bóg przepasał Ją zdrowiem i uczynił Jej drogę nieskalaną (por. Ps 18[17],33) ${ }^{35}$. Myśl tę kontynuuje oracja pochodząca z tekstów uroczystości Deus, qui per Immaculatam Virgi-

\footnotetext{
${ }^{30}$ Por. Giulio D'Onofrio, Historia Teologii. II. Epoka średniowieczna (Kraków: Wydawnictwo M, 2005), 490.

${ }^{31}$ Por. Arkadiusz Baron, Henryk Pietras, opr., Dokumenty soborów powszechnych, t. III (Kraków: Wydawnictwo WAM, 2003), 425.

${ }^{32}$ Por. Pius IX, Bulla: Ineffabilis Deus (Warszawa: Te Deum, 2004), 21.

${ }^{33}$ Por. BR 1778, s. CCXLIV.

${ }^{34}$ Por. Breviarium Romanum. Ex decreto SS Concilii Tridentini restitutum, S. Pii V. Pontificis Maximi jussu editum, Clementis VIII. et Urbani VIII. auctoritate recognitum. Pars aestiva. Cum adprobatione Sacr. Rituum Congregationis (Ratisbonae, Neo Eboraci \& Cincinnatii, Sumptibus, Chartis et typis Friderici Pustet, S. Sedis Apostolicae Typographi, MDCCCLXXIX), [III] [dalej: BR 1879, aestiva].

35 Por. BR 1879, aestiva, [III].
} 
nis Conceptionem..., która została przywrócona po ogłoszeniu dogmatu i jest autorstwa Leonarda Nogaroli (zm. ok. 1425) ${ }^{36}$. W tej modlitwie podkreślono, że przez ten fakt Bóg przygotował miejsce zamieszkania dla swego Syna i ze względu na moc zasług Jego śmierci zachował Maryję od wszelkiej zma$\mathrm{zy}^{37}$. Idea Niepokalanego Poczęcia została tu oddana za pomocą ściśle określonych terminów teologicznych, podkreślając odkupienie zachowawcze, czyli ustrzeżenie Maryi ze względu na zasługi śmierci Jezusa ${ }^{38}$. Myśl tę ukazują również dwa określenia Maryi z hymnu do matutinum Praeclara custos Virginum, gdzie została ona nazwana przeczystą strażniczką dziewic (praeclara custos virginum) oraz nietkniętą Matką Boga (intacta mater Numinis) ${ }^{39}$.

Przedstawiając dziewicze macierzyństwo Maryi w tekstach liturgicznych porównywano Bogarodzicę do szczęśliwej bramy niebieskiej (felix caeli por$t a)^{40}$. Termin ten występuje $\mathrm{w}$ jednym $\mathrm{z}$ najstarszych hymnów maryjnych Ave maris Stella, który odmawiano w nieszporach tego oficjum, a pochodzi od anonimowego autora z przełomu VII/VIII w. Hymn ten początkowo odmawiano w uroczystość Zwiastowania ${ }^{41}$. Podobnie w hymnie matutinum: przywoływano Maryję jako bramę niebios (coelestis aulae janua) ${ }^{42}$, a w hymnie laudesów $O$ gloriosa Virginum okreslano Matkę Pana jako bramę wielkiego Króla (tu regis alti janua $)^{43}$.

Chwalebne poczęcie Dziewicy Maryi, dzięki któremu Rodzicielka otrzymała godność i nie utraciła dziewiczej wstrzemięźliwości, wychwalano słowami invitatorium $\mathrm{z}$ oficjum sprzed reformy za papieża Piusa $\mathrm{IX}^{44}$. Ta dziewicza brama, przez którą przyszło zbawienie, miała pozostać zamknięta. Do tych treści nawiązuje czytanie z seksty oficjum po ogłoszeniu dogmatu. Słowami proroka Ezechiela w odniesieniu do Maryi podkreślano niejako, ,że brama ma być zamknięta. Nie powinno się jej otwierać i nikt nie powinien przez nią wchodzić, albowiem Pan, Bóg Izraela, wszedł przez nią. Jedynie władca może

${ }^{36}$ Por. Rutkowski, „Niepokalane Poczęcie NMP. III Kult”, 1170.

${ }^{37}$ Por. BR 1879, aestiva, [II].

${ }^{38}$ Por. Julian Wojtkowski, „Niepokalane Poczęcie Najświętszej Maryi Panny w oficjach brewiarzowych i formularzach mszalnych Leonarda de Nogarolis i Bernardyna de Bustis”, Ruch Biblijny i Liturgiczny 7(1954): 135.

${ }^{39}$ Por. BR 1879, aestiva, [II].

${ }^{40}$ Por. BR 1879, aestiva, [II].

${ }^{41}$ Por. Alex Stock, Lateinischen Hymnen (Berlin: Verlag der Weltreligionen, 2012), 118120.

${ }^{42}$ Por. BR 1879, aestiva, [II].

${ }^{43}$ Por. BR 1879, aestiva, [IX].

${ }^{44}$ Por. BR 1778, CCXLIV. 
w niej zasiadać" (por. Ez 44,2-3) ${ }^{45}$. Wprawdzie teologowie interpretowali zamkniętą bramę jako symbol Maryi Dziewicy, ale ma tu miejsce nawiązanie do bramy wschodniej dziedzińca wewnętrznego świątyni jerozolimskiej, przez którą powróciła chwała Boża i uświęciła świątynię, albo do Bramy Złotej w murze świątynnym, która powinna być zamknięta w oczekiwaniu na przyjście Mesjasza ${ }^{46}$. Również do tematu „zamknięcia” nawiązuje responsorium po siódmym czytaniu, gdzie przytoczono słowa z Pieśni nad Pieśniami: „Ogrodem zamkniętym jesteś, siostro ma, oblubienico, ogrodem zamkniętym, źródłem zapieczętowanym... Otwórz mi, siostro moja, przyjaciółko moja, gołąbko moja, ty moja nieskalana" (Pnp 4,12; 5,2) ${ }^{47}$. Teksty liturgiczne oficjum wotywnego uwypuklają znaczenie dziewiczego macierzyństwa. Maryja nazywana jest zawsze dziewica - Panną (semper Virgo), jedyna - sławna (singularis) i ze wszystkich najmilszą - cichą (inter omnes mitis), o czym wspomina hymn nieszporny ${ }^{48}$. Występujące tytuły podkreślają chrystocentryzm tekstów oficjum ${ }^{49}$.

W tekstach liturgicznych oficjum wotywnego można odnaleźć wiele innych metafor wskazujących na czystość Maryi. Należy do nich porównanie czystości Maryi do śniegu na Libanie, czy Jej piękna i słodyczy do plastra miodu (por. Pnp 4,11), o czym przypominano w responsorium po trzecim czytaniu I nokturnu. Ona została bowiem ukoronowana koroną chwały (por. Pnp 4,7. $11)^{50}$. Ona jest również określana w hymnie matutinum: Praeclara custos virginum jako gołąbko lśniąca pięknością (Columba formosissima), lilia wyrosła wśród cierni (Inter rubéta lilium), różdżka lecząca (Virga e radice gérminans), przewodnia gwiazda rozbitków (Aamica stella naufragis) czy wieża niezdobyta przez szatana (Turris dracóni impèrvia) ${ }^{51}$.

Macierzyństwo Maryi zostało przygotowane przez Boga od wieków. Na tę odwieczność wskazuje ukazanie Maryi w relacji do stworzonej przed wiekami Mądrości Bożej. To odniesienie powraca do dawnej tradycji liturgicznej Kościoła, gdyż w święta maryjne odczytywano fragmenty z ksiąg mądrościo-

\footnotetext{
45 Por. BR 1879, aestiva, [IX].

46 Por. Jesus Asurmendi Ruiz, „Księga Ezechiela”, w Międzynarodowy komentarz do Pisma Świętego, red. William R. Farmer (Warszawa: Verbinum, 2001), 978.

${ }^{47}$ Por. BR 1879, aestiva, [VI]-[VII].

48 Por. BR 1879, aestiva, [II].

${ }^{49}$ Por. Wojtkowski, „Niepokalane Poczęcie Najświętszej Maryi Panny”, 116.

${ }^{50}$ Por. BR 1879, aestiva, [III].

${ }^{51}$ Por. BR 1879, aestiva, [III].
} 
wych $^{52}$. Maryjną interpretację tych tekstów podawało wielu pisarzy chrześcijańskich. W takim duchu interpretował ten fragment Honoriusz z Autun (zm. ok. 1151) w Sigillum Beatae Mariae ${ }^{53}$. Obrazu tego jednak nie należy postrzegać jako proroctwa czy typologii, gdyż Mądrość jest hipostazą Boga. W odniesieniu do Maryi jest jedynie akomodacją, która bardziej znajduje swoje uzasadnienie w liturgicznej tradycji Kościoła ${ }^{54}$. W krótkich czytaniach biblijnych podkreślano, że Bóg stworzył Mądrość przed wiekami, jako swe arcydzieło. Od wieków została stworzona i zaczęła istnieć przed oceanem (por. Prz 8, 22-24) ${ }^{55}$. W liturgii przed reformą Piusa IX również wskazywano na odwieczność Mądrości Bożej. Ona również nie przestanie istnieć i w Jego obecności w świętym Przybytku zaczęła pełnić świętą służbę (por. Syr 24,9-10) ${ }^{56}$. Podobnie w pierwszym responsorium II nokturnu przypomniano słowa o odwiecznej Mądrości stworzonej przed wiekami, która wyszła $\mathrm{z}$ ust Najwyższego i została poczęta zanim powstały głębiny, albowiem Pan stworzył ją w sprawiedliwości, wziął ją za rękę i ją zachował (por. Syr 24,3-4, Prz 8,24) ${ }^{57}$.

Macierzyństwo Maryi stanowiło początek zbawienia, gdy została wybrana na dziewiczą Matkę Chrystusa. Ona usłyszała owo wezwanie Ave od Gabriela (Sumens illud Ave Gabrielis ore), dlatego Matka Boża określana jest także jako Dei Mater alma, co znajduje swój wyraz w słowach hymnu nieszpornego $^{58}$. Z języka hebrajskiego alma oznacza dziewice i panne ${ }^{59}$. Syntezą tej myśli teologicznej jest sam hymn Magnificat, którego istotne treści powracaja w tekstach oficjum wotywnego. Zwłaszcza te treści są obecne w responsoriach po czytaniach nokturnów. Podkreślano w nich Jej wybranie spośród innych niewiast i fakt, że rzeczywiście Pan uczynił wielkie rzeczy Maryi, a swoje miłosierdzie okazał $\mathrm{z}$ pokolenia na pokolenie (por. Łk 1,48-50), a myśl ta występuje w siódmym responsorium sprzed reformy za papieża Piusa $\mathrm{IX}^{60}$. Po reformie w ósmym responsorium uwypuklano, że to wybra-

\footnotetext{
52 Por. Antoni Tronina, Zawitaj Pani świata. Obrazy i symbole biblijne w Godzinkach o Niepokalanym Poczęciu NMP (Niepokalanów: Wydawnictwo Ojców Franciszkanów, 1995), 21.

${ }^{53}$ Por. Honorius Augustodunensis, Sigillum Beatae Mariae ubi exponuntur Cantica Canticorum, PL 172, 498-542.

${ }^{54}$ Por. Rene Laurentin, Matka Pana. Krótki traktat teologii maryjnej (Warszawa: Wydawnictwo Księży Marianów, 1989), 248-249.

${ }^{55}$ Por. BR 1879, aestiva, [VIII].

${ }^{56}$ Por. BR 1778, CCXLIV.

${ }^{57}$ Por. BR 1879, aestiva, [IV].

${ }^{58}$ Por. BR 1879, aestiva, [II].

${ }^{59}$ Por. Jougan, Stownik kościelny tacińsko-polski, 30.

${ }^{60}$ Por. BR 1778, CCXLIV.
} 
nie Maryi będzie motywem do wychwalania Jej przez wszystkie pokolenia (Łk 1,46.48-49) ${ }^{61}$. Również antyfona do Magnificat I nieszporów wskazywała na fakt, że Maryję będą nazywać błogosławioną wszystkie pokolenia, gdyż wielkie rzeczy Jej uczynił ${ }^{62}$. Tę antyfonę odmawiano również podczas samej uroczystości -8 grudnia $^{63}$. Według liturgii, przed reformą Piusa IX, wpisując powołanie Maryi w historię zbawienia podkreślano, że pochodziła Ona z potomstwa Abrahama, z pokolenia Judy, z rodu Dawida ${ }^{64}$.

$\mathrm{Na}$ wzajemne relacje pomiędzy macierzyństwem, jako początkiem zbawienia, a Niepokalanym Poczęciem Maryi wskazuje występująca do reformy papieża Piusa IX oracja: Famulis tuis..., w której modlący prosił o udzielenie daru łaski niebiańskiej. Skoro bowiem Macierzyństwo stało się dla ludzi początkiem zbawienia, tak wspomnienie Poczęcia Maryi miało sprawić, aby Pan pomnożył pokój ${ }^{65}$. Modlitwa ta stanowiła adaptację oracji odmawianej w dzień Narodzenia Najświętszej Maryi Panny oraz Jej Nawiedzenia ${ }^{66}$.

\section{MYSTERIUM INIQUITATIS A PIĘKNO MARYI}

Niepokalane Poczęcie Najświętszej Maryi Panny wpisane jest w całą historię zbawienia. W antyfonie do Benedictus oficjum po reformie papieża Piusa IX przypomniano, że świętowanie Niepokalanego Poczęcia jest podkreśleniem faktu, że Maryja swoją dziewiczą stopą zmiażdżyła głowę węża. Przypomniano tu obietnicę z Księgi Rodzaju, kiedy Niewiasta zmiażdży głowę szatana (por. Rdz 3,14-15) ${ }^{67}$. W oficjum sprzed reformy za papieża Piusa IX wspominano odwieczne poczęcie Bogarodzicy Dziewicy Maryi i Jej chwałę, która dzięki temu wydarzeniu wstąpiła na wyniosły $\operatorname{tron}^{68}$.

Myśl o grzechu i o zbawieniu zarysowana została w responsoriach do czytań I nokturnu. Podkreślano tu, że przez jednego człowieka grzech wszedł do całej ludzkości, która zgrzeszyła (por. Rz 5,12). Dlatego przypomniano

\footnotetext{
${ }^{61}$ Por. BR 1879, aestiva, [VII].

62 Por. BR 1879, aestiva, [II].

${ }^{63}$ Por. BR 1879, hiemalis, 481.

${ }^{64}$ Por. BR 1778, CCXLIV.

${ }^{65}$ Por. BR 1778, CCXLIV.

${ }^{66}$ Por. Manlio Sodi, Alessandro Toniolo, Placide Bruylants, opr., Liturgia Tridentina, FontesIndices-Concordantia 1568-1962 (Città del Vaticano: Libreria Editrice Vaticana, 2010), 364.

${ }^{67}$ Por. BR 1879, aestiva, [IX].

${ }^{68}$ Por. BR 1778, CCXLIV.
} 
słowa anioła, aby Maryja się nie bała, gdyż znalazła łaskę u Pana (por. Łk 1,30). On bowiem wybawił Jej duszę od śmierci (por. Ps 116 [115]) ${ }^{69}$. W oficjum sprzed reformy za papieża Piusa IX wychwalano Maryję, że pochodzi Ona z potomstwa Dawida, dzięki której objawiło się zbawienie dla wierzących, a której chwalebne życie dało światło dla świata ${ }^{70}$. Maryja przez to stała się narzędziem, dzięki któremu w mocy Ducha Świętego został zrealizowany Boży plan zbawienia ${ }^{71}$.

Na piękno Maryi wskazywano w antyfonach drugiego nokturnu. W pierwszej z nich: „Diffusa est...” podkreślano, że wdzięk się rozlał podczas Jej poczęcia, na Jej wargach i jako piękna ukazała się pośród synów ludzkich (por. Ps 45[44],3). Podobnie Bóg jest w Jej wnętrzu, a Najwyższy uświęcił swój przybytek (por. Ps 46[45],6). Ją bowiem będą wzywać jako błogosławioną, gdyż została niejako zbudowana jak miasto na wysokiej górze (por. Ps 87[86],1-3). Po tym bowiem można poznać, że Bóg jest dla niej łaskawy, gdyż wróg nie odniesie nad nią triumfu (Ps 41[40],12) ${ }^{72}$.

Piękno Maryi i Jej sławne życie ma rozświetlać cały Kościół, co też podkreślano w wersecie przed Magnificat w oficjum sprzed reformy papieża Piusa $\mathrm{IX}^{73}$. Podobnie antyfony do psalmów III nokturnu nowego oficjum tworzą sekwencje motywów do wychwalania Matki Pana. Zachęcano, aby świętość i wspaniałość poczęcia Maryi ogłaszać pośród wszystkich narodów (por. Ps 96[95],2-3), aby wszyscy wysławiali Pana i wychwalali pamiątkę Jego świętości (por. Ps 30 [29],5), dlatego, że Pan okazał swoje zbawienie: na oczach narodów i objawił swą chwałę wobec swojej Rodzicielki (por. Ps 98[97],2) ${ }^{74}$.

Zachowanie piękna w Maryi przez Boga sprawiło, że nic skażonego do Niej nie przylgnęło, dlatego przez analogię można spojrzeć na Maryję, jako odblask wieczystej światłości, zwierciadło bez skazy działania Boga i obraz Jego dobroci. Na wolność Maryi od wszelkiej skazy wskazuje interpretacja słowa Ave, które czytając a vae oznacza sine vae, czyli „bez biada”, ${ }^{75}$. Ona jest piękniejsza niż słońce i wszelki gwiazdozbiór, jaśniejąc ponad wszystko (por. Mdr 7,25-26.29). Podobnie w responsorium po szóstym czytaniu II nok-

\footnotetext{
${ }^{69}$ Por. BR 1879, aestiva, [III].

${ }^{70}$ Por. BR 1778 , CCXLIV.

${ }^{71}$ Por. Adrian Leske, „Ewangelia według św. Mateusza”, w Międzynarodowy komentarz do Pisma Świętego, red. William R. Farmer (Warszawa: Verbinum, 2001), 1146.

72 Por. BR 1879, aestiva, [III]-[IV].

${ }^{73}$ Por. BR 1778, CCXLIV.

74 Por. BR 1879, aestiva, [V].

75 Por. Wojtkowski, „Niepokalane Poczęcie Najświętszej Maryi Panny”, 116.
} 
turnu wskazywano na Maryję jako wielki znak, który ukazał się na niebie: niewiasty obleczonej w słońce i księżyc pod Jej stopami, a na jej głowie wieniec z gwiazd dwunastu. To bowiem Bóg przyodział ją w szaty zbawienia, okrył ją płaszczem sprawiedliwości, jak oblubieńca, który wkłada zawój, jak oblubienicę strojną w swe klejnoty (por. Iz 61,10; Ap 12,1) ${ }^{76}$. Obraz niewiasty $\mathrm{z}$ Apokalipsy przypominano również $\mathrm{w}$ czytaniu podczas nony ${ }^{77}$. Jeszcze wyraźniej podkreślano chwałę Maryi słowami antyfon do laudesów. Ona jest bowiem cała piękna i zmazy pierworodnej w Niej nie ma. Jej bowiem szaty są białe jak śnieg, a Jej oblicze jako słońce (por. Dn 7,9). Ona jest również chwała Jerozolimy, weselem Izraela i chlubą chrześcijan (por. Jdt 15,9). Maryja jest błogosławiona ponad wszystkie niewiasty na ziemi (por. Jdt 13,18). Dlatego w ostatniej antyfonie błagano, aby Dziewica Niepokalana pociagnęła wszystkich za sobą, aby doświadczyć jej piękna, co wyrażone jest w pięknym zapachu jej olejków (por. Pnp 1,4) ${ }^{78}$. Aleksander z Hales OFM (zm. 1245), komentując piękno Maryi podkreślał, że nie powstała w Niej żadna zmaza, ani grzechu pierworodnego, ani uczynkowego ${ }^{79}$.

Dawcą prawdziwego piękna jest sam Bóg, gdyż to On - jak zaznaczono $\mathrm{w}$ tekstach responsorium $\mathrm{w}$ tercji - mocą przepasuje i nienaganną czyni drogę (por. Ps 18[17],33). Po tym bowiem można poznać łaskawość Boga, a wróg nie odniesie triumfu (por. Ps 41[40],12) ${ }^{80}$. Niepokalane Poczęcie przyniosło bowiem całemu światu prawdziwą radość, co też zostało uwypuklone w antyfonie do Magnificat sprzed reformy tego oficjum ${ }^{81}$.

\section{WSTAWIENNICTWO MARYI NIEPOKALANEJ ZA SWOIM LUDEM}

Oddawanie czci Najświętszej Maryi Pannie jest ściśle związane z Jej wstawiennictwem, co też w Konstytucji dogmatycznej o Kościele określono jako macierzyństwo Maryi w ekonomii łaski, dlatego właściwe są stosowane wobec Niej tytuły, jak: Orędowniczka, Wspomożycielka, Pomocnica czy Pośredniczka (por. KK 62). Tę myśl wyraża hymn nieszporów odmawiany

\footnotetext{
${ }^{76}$ Por. BR 1879, aestiva, [V].

77 Por. BR 1879, aestiva, [X].

${ }^{78}$ Por. BR 1879, aestiva, [VIII].

${ }^{79}$ Por. Wojtkowski, „Niepokalane Poczęcie Najświętszej Maryi Panny”, 118.

${ }^{80}$ Por. BR 1879, aestiva, [IX].

${ }^{81}$ Por. BR 1778, CCXLV.
} 
również w oficjum wotywnym o Niepokalanym Poczęciu Najświętszej Maryi Panny w prośbie, aby Maryja okazała się dla wiernych matką (Monstra te esse matrem), a Chrystus, który zechciał być Jej synem (Tulit esse tuus), przez Nią przyjął zanoszone modlitwy (Sumat per te preces, Qui pro nobis natus $^{82}$. Słowami responsorium w I nokturnie oficjum sprzed reformy za papieża Piusa IX przypominano, że Maryja sama wstawia się za ludem u Pana Jezusa Chrystusa, a Jej modlitwy miały wspierać wiernych ${ }^{83}$. Oznacza to, że towarzyszy Ona swoim skutecznym wstawiennictwem przez całe dzieje Kościoła $^{84}$.

Na wstawiennictwo Maryi wskazuje tekst antyfony do Magnificat po reformie Piusa IX. Słowami tej antyfony zwracano się z prośbą do Maryi, aby pośpieszyła Ona z pomocą biednym, wspomagała tych, którym brakuje odwagi, pokrzepiała płaczliwych, modliła się za lud, wstawiała się za duchowieństwem, ręczyła za pobożnymi niewiastami, aby wszyscy, którzy czczą Jej święte Niepokalane Poczęcie, doświadczali Jej pomocy ${ }^{85}$. Również ta myśl została wyrażona w VIII responsorium oficjum wotywnego do połowy XIX w. ${ }^{86}$

Treści dotyczące wstawiennictwa Maryi zostały przedłożone w hymnie nieszpornym, a zawierały one prośbę o utwierdzenie wiernych $\mathrm{w}$ pokoju (Funda nos in pace) oraz odmianę losu - dosłownie zmianę imienia Ewa (Mutans Hevae nomen). Ta ostatnia prośba nawiązuje do Wcielenia, aby poprzez zgodę Maryi na wypełnienie woli Bożej nastąpiła zmiana losu ludzkości po grzechu pierworodnym. Święty Hieronim (zm. ok. 419) podkreśla, że imię Eva w języku hebrajskim oprócz życia - matki wszystkich żyjacych, oznacza również calamitas, czyli klęskę, szkodę, nieszczęście czy zniszczenie i niepowodzenie, dlatego odmiana losu miała wskazywać na szczęście i powodzenie $^{87}$. Dlatego w kolejnej strofie hymnu nieszpornego modlący się kierują prośbę, aby Matka Pana wyzwoliła winnych z więzów, przywróciła światło ślepym, oddaliła cierpienia i wyprosiła wszelkie łaski. Podobnie słowami hymnu matutinum proszono, aby Maryja ochraniała wiernych przed zdradami,

\footnotetext{
82 Por. BR 1879, aestiva, [II].

${ }^{83}$ Por. BR 1778 , CCXLIV.

${ }^{84}$ Por. Zdzisław Janiec, Wstawiennictwo Maryi (Sandomierz: Wydawnictwo Diecezjalne i Drukarnia w Sandomierzu, 2010), 96.

${ }^{85}$ Por. BR 1879, aestiva, [X].

${ }^{86}$ Por. BR 1778, CCXLIV.

${ }^{87}$ Por. S. Hieronymus, Liber De Nominibus Hebraicis, PL 23, 778.
} 
kierowała swoim światłem, rozpraszała ciemności błędnych dróg, broniła przed zdradliwą mielizną i zabłąkanym ukazywała bezpieczną drogę $e^{88}$.

Istotne treści teologiczne odnośnie do Niepokalanego Poczęcia Najświętszej Maryi Panny ukazane zostały w hymnach, antyfonach responsoriach, wersetach, modlitwach i krótkich czytaniach oficjum wotywnego. Dopełnieniem tych prawd były czytania poszczególnych nokturnów. Wprawdzie w I nokturnie nie przewidziano oddzielnych czytań biblijnych, ale własne teksty, pochodzące z oktawy uroczystości Niepokalanego Poczęcia Najświętszej Maryi Panny, przewidziano w II i III nokturnie. Teksty czytań II nokturnu przed ogłoszeniem dogmatu zmieniały się co dwa miesiące i pochodziły z tekstów patrystycznych ${ }^{89}$. Czytania III nokturnu natomiast były komentarzem Ojców Kościoła do Ewangelii opisującej rodowód Jezusa (por. Mt 1,1$16)^{90}$. W oficjum wotywnym po zmianie - za papieża Piusa IX - w II nokturnie zapisano czytania z bulli Ineffabilis Deus i ułożono je według czterech tomów brewiarza ${ }^{91}$. Natomiast teksty Ojców Kościoła z III nokturnu oscylo-

${ }^{88}$ Por. BR 1879, aestiva, [II]-[III].

${ }^{89} \mathrm{~W}$ styczniu i w lutym teksty pochodziły z samej uroczystości i stanowiły fragment dzieła św. Ambrożego (zm. 397) Traktat o dziewicach (PL 16 [1845], 208-209); w marcu i w kwietniu, poza okresem Wielkiego Postu, czytania pochodziły z drugiego dnia oktawy i była to 194 mowa św. Augustyna (zm. 430) De Annuntiatione Dominica (PL 39, 2106-2107); w maju i w czerwcu teksty zaczerpnięto z trzeciego dnia oktawy i była to homilia św. Bernarda w niedzielę podczas oktawy Wniebowzięcia Najświętszej Maryi Panny (PL 183, 432-433); w lipcu i w sierpniu z piątego dnia oktawy odczytywano fragment dzieła św. Epifaniusza z Salaminy (zm. 403) Przeciw herezjom (PG 42, 727-731); we wrześniu i w październiku czytania pochodziły z siódmego dnia oktawy i stanowiły fragmenty tekstów trzech autorów: z listu św. Ambrożego biskupa do papieża Syrycjusza (PL 16, 1125), z listu św. Hieronima przeciwko Jowianowi (PL 22, 510) oraz św. Ireneusza (zm. ok. 202), biskupa, Przeciwko herezjom (PG 7, 1175-1176); w listopadzie i w grudniu czytania pochodziły z 8 dnia oktawy i również stanowiły fragmenty z trzech autorów: z komentarza św. Grzegorza Wielkiego (zm. 604) do Pierwszej Księgi Królewskiej (PL 79, 25), z listu św. Leona Wielkiego (zm. 461), papieża, do Pulcherii (PL 54, 792), oraz św. Bazylego (zm. 379), biskupa, z komentarza do Księgi proroka Izajasza (PG 30, 478); por. BR 1778, s. 672. 674-677. 679-680. 683-686.

90 Teksty czytań III nokturnu były również ułożone w cyklu dwumiesięcznym i począwszy od stycznia i lutego były to następujące czytania: z homilii św. Augustyna do Ewangelii św. Mateusza (PL 34, 1071-1072), z komentarza św. Hieronima (zm. 419/420) do Ewangelii św. Mateusza (PL 26, 21. 23), z komentarza św. Hilarego (zm. 367) do Ewangelii św. Mateusza (PL 9, 919-921) i trzy kolejne fragmenty z homilii św. Jana Chryzostoma (zm. 407) do Ewangelii św. Mateusza (PG 57, 25-26; 26-27; 27-31); BR 1778, s. 673. 675-678. 680. 684-687.

${ }^{91} \mathrm{~W}$ okresie zimowym (hiemalis) czytania brano z drugiego dnia oktawy, w czasie wiosennym (verna) z 3 dnia oktawy, w okresie letnim (aestiva) z 5 dnia oktawy, a w okresie jesiennym (autumnalis) z 7 dnia oktawy; por. BR 1879, hiemalis, [XI]; BR 1879, verna, [XIII][XV]; por. BR 1879, aestiva, [IV]-[V]; BR 1879, autumnalis, [XIII]-[XIV]. 


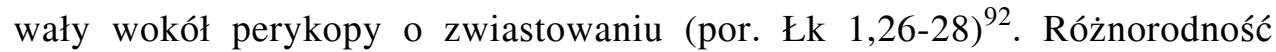
tych tekstów miała $\mathrm{z}$ jednej strony ubogacić wspominanie prawdy o Niepokalanym Poczęciu w częstszym cyklu niż raz w roku, a z drugiej strony ukazać fundamenty teologiczne tej prawdy w lex credendi Kościoła.

\section{PODSUMOWANIE}

Liturgia jako theologia prima odgrywała ważną rolę w kształtowaniu się świadomości prawd wiary, które stanowiły fundament modlitwy - lex orandi. Ta wzajemna relacja lex credendi-lex orandi znajdowała się u podstaw sformułowania dogmatu o Niepokalanym Poczęciu Najświętszej Maryi Panny w bulli papieża Piusa IX Ineffabilis Deus z 8 grudnia 1854. Wprawdzie prawda ta była obecna w liturgii już od wczesnych wieków chrześcijaństwa, to wprowadzenie tej prawdy było okazją do skomponowania nowych tekstów liturgicznych, które miały uwypuklać tę prawdę. Przykładem jest oficjum wotywne o tej tajemnicy znane w liturgii od XVIII do początku XX w.

Teksty oficjum wotywnego o Niepokalanym Poczęciu Najświętszej Maryi Panny w liturgii potrydenckiej uległy zmianie po ogłoszeniu dogmatu w 1854 r. i ostateczny kształt nadano im w 1863 r. Początkowo oficjum to wprowadzono w 1727 r. i można było je odmawiać w krajach znajdujących się pod władzą Austrii. Wówczas teksty tego oficjum najczęściej pochodziły z tekstów przeznaczonych na samą uroczystość i oktawę, z tekstów wspólnych lub z Officium parvum Beatae Mariae Virginis. W tekstach tych podkreślano przede wszystkim godność Maryi wynikająca z racji Jej wybrania.

Teksty liturgiczne oficjum wotywnego, wydane za papieża Piusa IX, ukazują Maryję w całym planie zbawienia i mają charakter chrystocentryczny. $\mathrm{Na}$ pierwszym miejscu podkreślają ścisły związek pomiędzy Niepokalanym Poczęciem a dziewiczym macierzyństwem Maryi. Od wieków bowiem Maryja została przygotowana przez samego Boga jako czyste mieszkanie dla Jego Syna. Otrzymując ten przywilej od Boga Maryja nie utraciła swojego dzie-

$92 \mathrm{~W}$ okresie zimowym (hiemalis) było to kazanie drugie św. Sofroniusza z Jerozolimy (zm. 638) o Zwiastowaniu Najświętszej Maryi Panny (PG 87, 3, 3235-3238); w czasie wiosennym (verna) z drugiej homilii św. Bernarda (zm. 1153) Missus est angelus Gabriel (PL 183, 62-63); w okresie letnim (aestiva) z homilii św. Tarazjusza (zm. 806) na Ofiarowanie Najświętszej Maryi Panny (PG 98, 1490-1495. 1498-1499); a w okresie jesiennym (autumnalis) z drugiego kazania o Zwiastowaniu Najświętszej Maryi Pannie (PG 87, 3, 3246-3247); por. BR 1879, hiemalis, [XI]; BR 1879, verna, [XV]-[XVI]; BR 1879, aestiva, [VI]-[VIII]; BR 1879, autumnalis, [XV]-[XVI]. 
wictwa, dlatego ważną rolą było ukazanie piękna Maryi na tle misterium grzechu pierworodnego i obietnicy z Protoewangelii z Księgi Rodzaju. Myśl tę w oficjum uwypuklały teksty z Księgi Mądrości, Pieśni nad Pieśniami oraz z tekstów Ojców Kościoła. Wychwalając Maryję Pannę słowami oficjum wotywnego, proszono o Jej wstawiennictwo.

Teksty oficjum wotywnego o Niepokalanym Poczęciu Najświętszej Maryi Panny pozwalały na wyznawanie tej prawdy w lex orandi nie tylko z racji samej uroczystości i jej oktawy, ale nawet w cyklu cotygodniowym - zgodnym z obowiązującymi rubrykami. Lektura i medytacja tekstów liturgicznych kształtuje więc właściwe postrzeganie kultu Maryi w tradycji Kościoła Zachodniego. Prawdziwa pobożność maryjna nie polega bowiem na uczuciu, ale na kształtowaniu właściwej relacji synowskiej do Bogarodzicy, naśladując Jej cnoty.

\section{BIBLIOGRAFIA}

Baron, Arkadiusz, Pietras, Henryk, opr. Dokumenty soborów powszechnych. Kraków: Wydawnictwo WAM, 2003.

Bäumer, Suitbert. Geschichte des Breviers. Freiburg im Breisgau: Herder, 1895.

Breviarium Romanum. Ex decreto Sacrosancti Concilii Tridentini restitutum, S. Pii V. Pontificis Maximi jussu editum, Clementis VIII. \& Urbani VIII. Aauctoritate recognitum. In quo officia novissima sanctorum accurate sunt disposita, Ex ducali Campidonensi Typograheo, Per Aloysium Galler, Anno Domini MDCCLXXVIII.

Breviarium Romanum. Ex decreto SS Concilii Tridentini restitutum, S. Pii V. Pontificis Maximi jussu editum, Clementis VIII. et Urbani VIII. auctoritate recognitum. Pars aestiva. Cum adprobatione Sacr. Rituum Congregationis. Ratisbonae: Neo Eboraci \& Cincinnatii, Sumptibus, Chartis et typis Friderici Pustet, S. Sedis Apostolicae Typographi, MDCCCLXXIX.

D’Onofrio, Giulio. Historia teologii. II. Epoka średniowieczna. Kraków: Wydawnictwo M, 2005.

Danielski, Wojciech. „Brewiarz”. W Encyklopedia Katolicka, t. 2, red. Feliks Gryglewicz, 1064-1071. Lublin: Towarzystwo Naukowe KUL, 1995.

Decreta authentica Congregationis Sacrorum Rituum ex actis eiusdem collecta, eiusque Auctoritate promulgata sub auspiciis ss. Domini Nostri Leonis Papae XIII. Vol III. Romae: Ex Typographia Polyglotta, MDCCCC.

Decreta authentica Congregationis Sacrorum Rituum ex actis ejusdem Sacr. Congr. collecta cura et studio sacerdotis Aloysii Gardellini ejusdem S.R.C. assesoris, et sub-promotoris fidei, Editio altera emendator, Tomus quartus. Romae: Typis Francisci, et Leopoldi Bourlié, MDCCCXXV.

Decreta authentica Congregationis Sacrorum Rituum ex actis ejusdem Sacr. Congr. collecta cura et studio sacerdotis Aloysii Gardellini ejusdem S.R.C. assesoris, et sub-promotoris fidei, Editio altera emendator, Tomus quintus. Romae: Typis Francisci, et Leopoldi Bourlié, MDCCCXXV. 
Decreta authentica Congregationis Sacrorum Rituum nunc primum ex actis ejusdem S. Congregationis collecta. Continuatio appendicis. Romae: Typis S. Congregationis de Propaganda Fide, MDCCCXLIX.

Honorius Augustodunensis. Sigillum Beatae Mariae ubi exponuntur Cantica Canticorum. PL $172,495-542$.

Janiec, Zdzisław. Wstawiennictwo Maryi. Sandomierz: Wydawnictwo Diecezjalne i Drukarnia w Sandomierzu, 2010.

Jougan, Alojzy. Stownik kościelny tacińsko-polski. Warszawa: Wydawnictwo Archidiecezji Warszawskiej, 1992.

Laurentin, Rene, Matka Pana. Krótki traktat teologii maryjnej. Warszawa: Wydawnictwo Księży Marianów, 1989.

Leske, Adrian. „Ewangelia według św. Mateusza”. W Międzynarodowy komentarz do Pisma Świętego, red. William R. Farmer, 1140-1209. Warszawa: Verbinum, 2001.

Leszczyński, Rafał Marcin. „Prosper z Akwitanii”. W Encyklopedia Katolicka, t. 16, red. Edward Gigilewicz, 508-509. Lublin: Towarzystwo Naukowe KUL, 2012.

Nadolski, Bogusław. Leksykon liturgii. Poznań: Pallottinum, 2006.

Napiórkowski, Stanisław. „Niepokalane Poczęcie NMP. I. Teologia. 1. W Kościele katolickim”. W Encyklopedia Katolicka, t. 13, red. Edward Gigilewicz, 1166-1167. Lublin: Towarzystwo Naukowe KUL, 2009.

Nowowiejski, Antoni Julian. Wykład Liturgji Kościoła Katolickiego, t. IV, cz. II. Płock: Tłocznia „Kurjera płockiego” i „Mazura”, 1916.

Pius IX. Bulla: Ineffabilis Deus. Warszawa: Te Deum, 2004.

Prosper ex Aquitania. Liber cui titulus praeteritorum sedis apostolicae episcoporum auctoritates, de gratia Dei et libero voluntatis arbitrio, PL 51, 205-211.

Ruiz, Jesus Asurmendi. „Księga Ezechiela”. W Międzynarodowy komentarz do Pisma Świętego, red. William R. Farmer, 949-979. Warszawa: Verbinum, 2001.

Rutkowski, Andrzej. „Niepokalane Poczęcie NMP. III Kult”. W Encyklopedia Katolicka, t. 13, red. Edward Gigilewicz, 1168-1172. Lublin: Towarzystwo Naukowe KUL, 2009.

S. Congregatio Rituum. „Decretum Urbis et orbis”. Acta Sanctae Sedis 16(1883/1884): 47-48.

S. Congregatio Rituum. „Decretum: De privilegio officii divini iuxta veterem psalterii ordinem recitandi”. Acta Apostolicae Sedis 5(1913): 96-97.

S. Congregatio Rituum. „Missae votivae per annum”. Acta Sanctae Sedis 16(1883/1884): 176180.

S. Congregatio Rituum. „Officia votiva per annum” Acta Sanctae Sedis 16(1883/1884): 145176.

S. Congregatio Rituum. „Rubricae in recitatione divini officii et in missarum celebratione servandae ad normam constitutionis Apostolicae Divino afflatu". Acta Apostolicae Sedis 3(1911): 639-651.

S. Congregatio Rituum. „Urbis et orbis”. Acta Apostolicae Sedis 4(1912): 57-82.

S. Hieronymus. Liber De Nominibus Hebraicis. PL 23, 771-934.

Sodi, Manlio, Toniolo, Alessandro, Bruylants, Placide, opr. Liturgia Tridentina, Fontes-IndicesConcordantia 1568-1962. Città del Vaticano: Libreria Editrice Vaticana, 2010.

Sodi, Manlio, Triacca, Achille Maria. „Introduzione”. W Breviarium Romanum. Editio Princeps (1568). Edizione anastatica, Introduzione e Appendice, ed. Manlio Sodi, Achille Maria Triacca, VII-XVIII. Città del Vaticano: Libreria Editrice Vaticana, 1999.

Stock, Alex. Lateinischen Hymnen. Berlin: Verlag der Weltreligionen, 2012.

Tronina, Antoni. Zawitaj Pani świata. Obrazy i symbole biblijne w Godzinkach o Niepokalanym Poczęciu NMP. Niepokalanów: Wydawnictwo Ojców Franciszkanów, 1995. 
Wojtkowski, Julian., „Niepokalane Poczęcie Najświętszej Maryi Panny w oficjach brewiarzowych i formularzach mszalnych Leonarda de Nogarolis i Bernardyna de Bustis". Ruch Biblijny i Liturgiczny 7(1954): 106-138.

\author{
NIEPOKALANE POCZECIE NAJŚWIETSZEJ MARYI PANNY \\ W LEX ORANDI KOŚCIOŁA W ŚWIETLE OFICJUM WOTYWNEGO \\ PO SOBORZE TRYDENCKIM
}

\author{
S t r e s z c z e n i e
}

Liturgia jako theologia prima odgrywała ważną rolę w kształtowaniu się świadomości prawd wiary, które stanowiły fundament modlitwy - lex orandi. Ta wzajemna relacja lex credendi-lex orandi znajdowała się u podstaw sformułowania dogmatu o Niepokalanym Poczęciu Najświętszej Maryi Panny w bulli papieża Piusa IX Ineffabilis Deus z 8 grudnia 1854. Wprawdzie to święto było obchodzone raz w roku, ale częstszą możliwość celebrowania tej tajemnicy - nawet cotygodniowa - dawało oficjum wotywne, które zostało wprowadzone do Officium Divinum w 1727 r., a po ogłoszeniu dogmatu w 1854 r. ostatecznie zatwierdzono nowe teksty w 1863 r. Oficja wotywne zostały zniesione w 1912 r. Teksty liturgiczne pozwalają we właściwym świetle ukazać tajemnicę Poczęcia Najświętszej Maryi Panny w lex orandi Kościoła po Soborze Trydenckim. Podkreślają one ścisły związek pomiędzy Niepokalanym Poczęciem a dziewiczym macierzyństwem Maryi. Od wieków bowiem Maryja została przygotowana przez samego Boga jako czyste mieszkanie dla Jego Syna. Otrzymując ten przywilej od Boga Maryja nie utraciła swojego dziewictwa. Dlatego ważną rolą było ukazanie piękna Maryi na tle misterium grzechu pierworodnego i obietnicy z Protoewangelii z Księgi Rodzaju. Myśl tę w oficjum uwypuklały teksty z Księgi Mądrości, Pieśni nad Pieśniami oraz z tekstów Ojców Kościoła. Wychwalając Maryję Pannę słowami oficjum wotywnego proszono o Jej wstawiennictwo w codziennym życiu, ale również o pomoc w dążeniu do zbawienia. Lektura i medytacja tekstów liturgicznych kształtuje więc właściwe postrzeganie kultu Maryi w tradycji Kościoła Zachodniego.

Słowa kluczowe: liturgia; Niepokalane Poczęcie Najświętszej Maryi Panny; oficjum wotywne; Sobór Trydencki. 